\title{
THE ROOT COLONIZING FUNGI OF THE TERRESTRIAL ORCHID CYPRIPEDIUM IRAPEANUM
}

\author{
María Valdés ${ }^{1,2}$, Héctor Bautista Guerrero ${ }^{1}$, Laura Martínez ${ }^{1} \&$ Rafael H. Víquez ${ }^{1}$ \\ ${ }^{1}$ Escuela Nacional de Ciencias Biológicas, Instituto Politécnico Nacional, Plan de Ayala y Carpio, \\ Colonia Santo Tomás, 11340 México D.F. \\ ${ }^{2}$ Author for correspondence: mvaldesr@ipn.mx
}

\begin{abstract}
This study investigated the mycorrhizal status and the identification of the fungi colonizing the roots of the terrestrial orchid Cypripedium irapeanu by restriction fragment length polymorphisms and by rDNA internal transcribed spacer sequencing. The orchid is endemic of differents regions in Mexico, Guatemala and Honduras; usually at 1400-2250 m. It grows mainly in the remaining oak forests of the highlands and it is in the Mexican red list of plants in danger. The oak forests in Mexico are threatened constantly. The microscopic examination of stained root segments of the orchid revealed the presence of fungal structures of both orchidioid fungi (pelotons and coyled hyphae) and dark septate endophytes (DSE) (mielinized hyphae and microsclerotia). Analysis of ITS1-5.8-ITS2 region sequences suggested that mycorrhizal tissue was dominated by Tulasnaceae: Sistotrema sp., Rhizoctonia solani, and Epulorhiza sp. Among the DSE one isolate revealed $100 \%$ similarity to Phomopsis sp XJ-05, and another one 99\% to the fungal endophyte MUT 885 which are both reported as dark septate endophytes. The putative dark septate endophyte Phomopsis sp XJ-05 was isolated not only from the roots but also from the germinated seeds of C. irapeanum.
\end{abstract}

RESUMEN. Este estudio investigó el status micorrízico y la identificación de los hongos que colonizan la raíz de la orquídea terrestre Cypripedium irapeanum por medio de los polimorfismos de los fragmentos de la restricción y la secuenciación del espacio tránscrito interno del rDNA. Esta orquídea es endémica de diferentes regiones de México, Guatemala y Honduras localizándose entre los 1400 y $2250 \mathrm{~m}$ de altitud. Crece principalmente en los remanentes de los bosques de encino del altiplano y está en la lista roja de México de las plantas amenazadas. Los bosques de encino en este país están constantemente amenazados. El examen al microscopio de los segmentos de raíces teñidas de las orquídeas nos mostró la presencia de estructuras fúngicas tanto de hongos de micorriza orquidoide (pelotones e hifas enrrolladas) como de los llamados endófitos obscuros septados (DSE) (hifas mielinizadas y microesclerosios). El análisis de la secuenciación de la región ITS1-5.6-ITS2 sugiere que el tejido micorrizado está dominado por Tulasneaceae: Sistotrema sp., Rhizoctonia solani, and Epulorhiza sp. Entre los DSE, uno de los 10 aislados mostró $100 \%$ de similaridad con Phomopsis sp XJ-05, y otro 99\% con el endofito MUT 885, ambos reportados como endófitos obscuros septados. El hipotético endófito septado obscuro Phomopsis sp XJ-05 fue aislado tanto de las raíces como de las semillas que germinaron de C. irapeanum restriction fragment length polymorphisms and by rDNA internal transcribed spacer sequencing.

KEY WORDS: terrestrial orchid, orchidoide mycorrhiza, dark septate endophytes, microsclerotia

Introduction. Symbiosis are particularly important for plants resulting in significant nutritional advantage. Among these are the mycorrhizae from which most plants obtain the majority of their nutrients, including those limiting their growth. In general for the terrestial orchids the mycorrhizal association is fundamental for the plant during germination and throughout all its life (Smith \& Read 1997).

Of all orchids that have been studied, few have been the object of mycorrhizal studies. Among the Mexican terrestrial orchids just $3 \%$ of the orchids have been studied (Ortega-Larrocea \& Rangel-Villafranco 2007).

Many species of terrestrial orchids are threatened or in danger due to the habitat loss by anthropogenic activities and the attractive beauty of its flowers (Dearnaley 2007). Cypripedium irapeanum (Fig. 1) grows mainly in the remaining oak forests of the Mexican highlands. The oak forests in Mexico are 


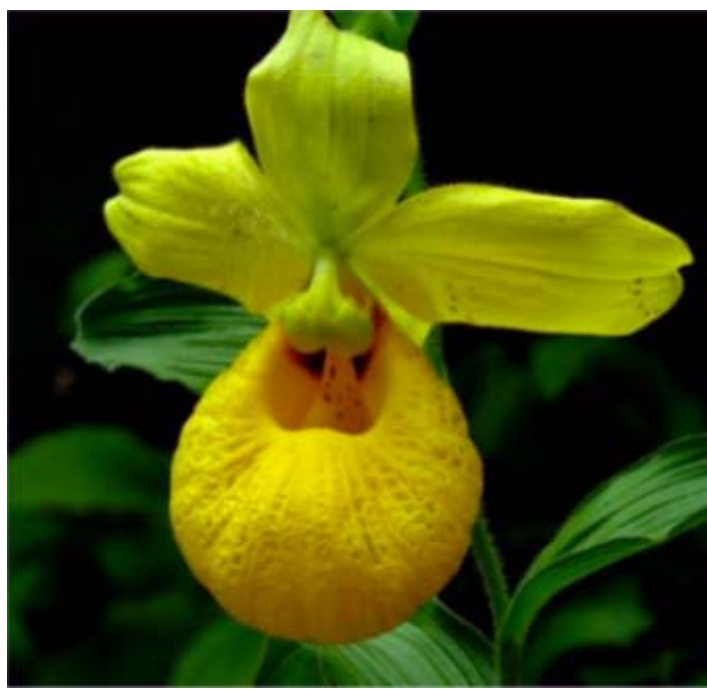

FIgure 1. Cypripedium irapeanum flower from Puebla State, Mexico.

threatened constantely by the urban activities and by the development of recreational sites. The change of soil use of the oak forests has conducted to the degradation by soil erosion and loss of these forests and have allow not only to the soil loss, and cosequently to the loss of the symbiotic fungi, but also to the decrease of the number of pollinators and to the increase of pathogens, specially the attack of the capsules by screw warms; other problems that this plant has to face in the degraded habitat are cattle, and weed invasion (Valdés et al. 2005).

Cypripedium irapeanum was orginally described based on a collection from the mountains of Irapeo near the present city of Morelia in Michoacan, Mexico (Cribb \& Soto Arenas 1993). In this country it is known as pichohuastle, a native name for the plant. The orchid is endemic of differents regions in Mexico (Chiapas, Durango, Guerrero, Jalisco, Michoacán, Morelos, Nayarit, Oaxaca, Sinaloa, Querétaro, Puebla, Veracruz), Guatemala and Honduras; usually at 1400$2250 \mathrm{~m}$ of altitud. The orchid is in the red list of plants in danger of the Mexican Department of Natural Resources (SEMARnat 1995).

In relation to the temperate lady's slipper orchids, Cypripedium, there are few studies on its associated fungi. According to Shefferson et al. (2005), the genus Cypripedium is characterized by high specificity mycorrhizal association, then the lack of these fungi may limit their establishment and distribution. Upon infection of this orchid by a compatible mycorrhizal fungus the seed ("dust seed") germinates into a seedling that consumes the fungal sugars, processus known as myco-heterotrophy. The plants may retain the myco-heterotrophy into adulthood (Gill 1989).

The internal transcribed spacer (ITS) regions of ribosomal DNA, including both ITS1 and ITS2, have been used extensively used for environmental sampling as a target because several taxonomic groupspecific primer sets exist for this gene region (Gardes $\&$ Bruns 1993). The ITS has been the region of choice for molecular analysis of fungal communities of this region has been useful since Gardes \& Bruns (1996) used its restriction digests (RFLP) to differenciate species of mycorrhizal fungi colonizing individual roots. Furthermore, the DNA sequences of the ITS1 and ITS2 are highly variable being a good marker to identify fungi to the genera and/or species level (Gardes \& Bruns 1993, Gardes \& Bruns 1996, Henrion et al. 1992, Smith et al. 2007).

Objective of this paper was the isolation and identification of the fungal root and seed endophytes as well as mycorrhyzal fungi of $C$. irapeanum by restriction fragment length polymorphisms and by rDNA internal transcribed spacer sequencing. The term "endophyte" refers to those fungi that can be detected at a particular moment within the tissues of apparentky healthy plant hosts (Schultz \& Boyle 2005).

Materials and methods. Collected C. irapeanum is surviving in a remaining patch of an oak forest which is located out of Puebla city in the State of Puebla, at $1840 \mathrm{~m}$. We collected C. irapeanum growing close to an oak tree.

Due to the scarcity of the orchids we obtained a collect autorization (No. D00.02-3478) from Semarnat. Cypripedium irapeanum plants were collected including the rhizome and the surrounded soill to ensure that the root system was kept intact. We also sampled seeds. The soil core with the alive whole plants were maintened in the greenhouse before to be processed.

In order to observe the root fungal colonization in situ the roots were hydrolyzed and stain by the Philips and Hayman procedures (1970) resulting in 20 to 30 root samples per plant. Inter and intracellular 
melanized hyphae with microslclerotia were recorded as Dark Septate Endophytes (DSE).

The isolation of the seed and root endophytes of C. irapeanum was done after a surface sterilization with a $5 \%$ sodium hipochlorite solution for $10 \mathrm{~min}$, followed by a $0.1 \%$ mercuric chloride solution for 2 min, and several washings with sterile distilled water. This drastic sterilization was done to prevent growth of root external microorganisms. Seeds were sowed in flasks containing Knudson (1946) culture medium, and the root fragments $(1 \mathrm{~cm} \mathrm{long})$ in Petri plates containing Melin-Norkrans (Molina \& Palmer, 1982) culture medium. After 4 days of incubation, plates with the root fragments having superficial contaminants were eliminated and those with no contaminants were incubated at $24^{\circ} \mathrm{C}$ for 3 months. Pure fungal isolates were propagated in Melin-Norkrans agar medium. Colonial and microscopic morphology was photographically documented (data not shown).

Genetic characterization of $C$. irapeanum endophytes involved 1) extraction of fungal DNA from isolated and purified fungi, 2) amplification of fungal genome region useful in determining fungal identity (ITS1-5.8S-ITS2), 3) restriction and RFLP analysis of the region, 4) DNA sequencing of the region, and 5) BLAST analysis for identification of endophytes.

DNA extraction of isolates was done utilizing the CTAB method (Gardes \& Bruns 1993). Obtained DNA was purified with the Concert Nucleic Acid Purification (Gibco), according to the manufacturer instructions. Concentration and purity of the DNA was evaluated with a GeneQuant spectrophotometer. The ITS region of the rRNA operon was amplified according to Gardes \& Bruns (1993) using the primers ITS1 (TCCGTAGGTGAACCTGCGC), ITS-1F (CTTGGTCATTTAGAGGAAGTAA), ITS 4 (TCCTCCGCTTATTGATATGC) and ITS4-B (CAGGAGACTTGTACACGGTCCAG). PCR was carried out in a Biometra-T personal termocycler under $94^{\circ} \mathrm{C}$ for $85 \mathrm{~s}$ for the denaturation followed by 25 cycles of amplification and extension for 13 cycles at $95^{\circ} \mathrm{C}$ for $35 \mathrm{~s}, 55^{\circ} \mathrm{C}$ for $55 \mathrm{~s}$ and $72^{\circ} \mathrm{C}$ for $45 \mathrm{~s}$. This was followed by an incubation at $72^{\circ} \mathrm{C}$ for 10 more minutes. Obtained bands were visualized in an $\mathrm{EtBr}$ stained agarose gel.

PCR products were purified (Concert Nucleic Acid, Gibco) and restricted with enzymes $\operatorname{Hinf} 1\left(\right.$ at $37^{\circ} \mathrm{C}$ for
5 hours), Alu1 (at $37^{\circ} \mathrm{C}$ for 1 hour), and $\operatorname{Taq} 1$ (at $65^{\circ} \mathrm{C}$ for 3 hours). Fragments were analiysed with the Kodak ID 3.6.1 program.

The amplicons were cloned and ligated using the TOPO XL PCR cloning (QIAGEN) according to the manufacturer's instructions. The recombinant vector was used for transforming cells of E. coli $\mathrm{DH} 5 \alpha$. Screening for recombinant cells was carried out by blue/white selection. Sequencing reactions were done in a Li-Cor $4202 \mathrm{G}$ sequencer. Before sequencing, the amplicons were purified with the Pure Link Quick Gel Extraction kit (Invitrogen) following the manufacturer's instructions.

Sequences were subjected to BLAST analysis to determine their homology with other sequences available in the Gene Bank for the ITS1-5.8S-ITS2 region. The CLUSTAL package (Thompson et al. 1994) was used to align the sequences with the corresponding fungal ITS rDNA sequences.

Results and discussion. The microscopic examination of stained root segments of the orchid revealed the presence of fungal structures of both orchidioid fungi, pelotons and coyled hyphae (Fig. 2) and DSE, mielinized hyphae and microsclerotia (Fig. 3). In $40 \%$ of the cortical cells pelotons were seen, and $30 \%$ of the cortical cells revealed the presence of microsclerotia inside the cells. We found partially digested pelotons in all C. irapeanum plants, suggesting that $C$. irapeanum may have mycoheterotrophic stages.

Table 1 shows the list of the endophytic fungi recovered from roots and germinated seeds of orchid Cypripedium irapeanum.

Dark Septate Endophytes were also observed in the germinated seeds. Two distinct types of microsclerotia were seen in the roots, one was of round shape and the other had irregular shapes (Fig. 3). A total of 10 different fungi were isolated, one from a germinated seed and 9 from the roots. Isolates 7, 9 and 10 were identified as DSE; Isolate 7 and 9 from the plants, and isolate 10 from the seeds. To our knowledge, this is the first report of the colonization of Cypripedium irapeanum by DSE fungi and the first report of the colonization and identification of both types of fungi in C. irapeanum.

As expected the amplified ITS1-5.8-ITS2 rDNA region resulted in a $650 \mathrm{bp}$ product. Negative controls 

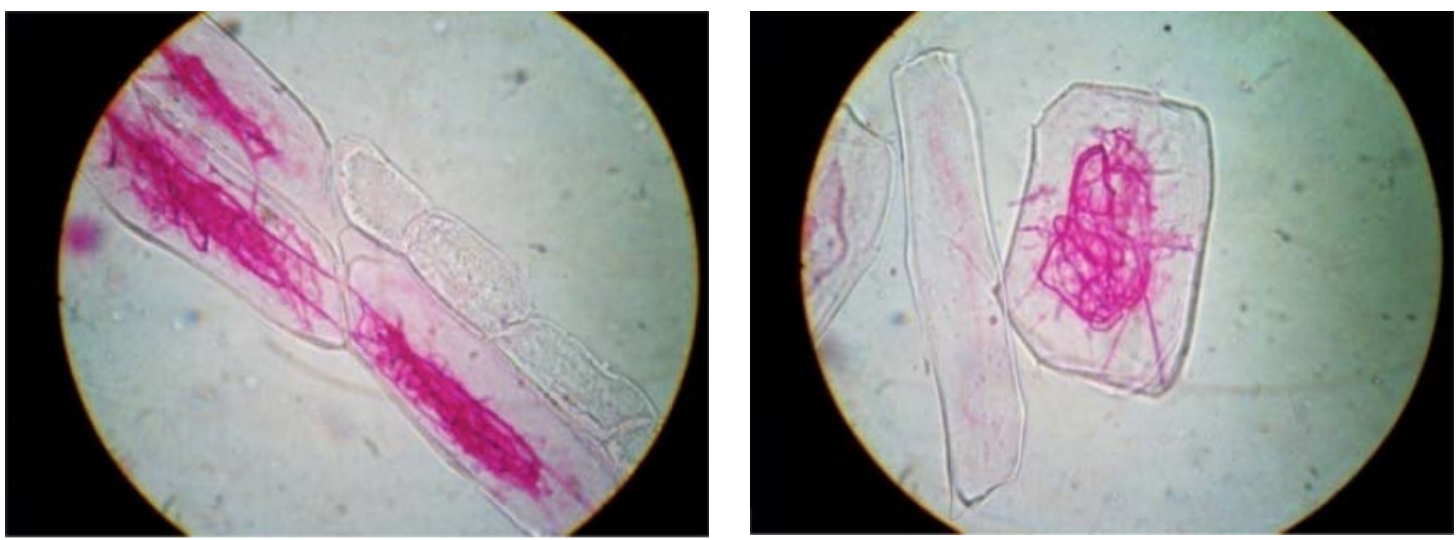

FIGURE 2. Squash preparation of a C. irapeanum stained root showing infection of cells, coiled hyphae and development of pelotons.

in PCRs (sterile milliporized water) consistently yielded no PCR product. The ITS 1F-ITS 4 combination yielded most of the PCR products except for the isolates 8,9 , and 10 which were amplified with the ITS 1-ITS 4B combination.

Restriction of the region yielded RFLPs different for all the analyzed fungi, except fot the isolates 9 and 10 that were identical. Nine RFLP patterns were yielded with $A l u \mathrm{I}$ and TaqI restriction enzymes and 7 patterns with HindI (Fig. 4), suggesting the diversity of the endophytes.

Analysis of ITS1-5.8-ITS2 region sequences suggested that mycorrhizal tissue was dominated by Tulasnaceae: isolate 2 (GeneBank Accesion No. JF313323) revealed 98\% identity to Sistotrema $s p$., isolate 3 (GeneBank Accesion No. JF313324) 99\% to Rhizoctonia solani, and isolate 6 (GeneBank Accesion No. JF313322) 97\% to Epulorhiza sp., confirming Shefferson et al. (2005) and Shimura et al. (2009) results for the genus Cypripedium. Diverse Tulasnaceae form mycorrhiza also with epiphytic orchids (Suárez et al. 2006). Figure 5 shows a phylogenetic tree indicating the placement of the mycorrhizal fungi recovered from the roots of C. irapeanum.

TABLE 1. Endophytic fungi recovered from roots and germinated seeds of orchid Cypripedium irapeanum

\begin{tabular}{|l|l|l|}
\hline Isolate & Molecular identification & Type of root colonizing fungus \\
\hline C1 & Fusarium & Fungal endophyte (Bayman \& Otero, 2006) \\
\hline C2 & Sistotrema & Mycorrhizal (Currah et al, 1990) \\
\hline C3 & Rhizoctonia solani & Mycorrhizal (Warcup, 1971) \\
\hline C4 & Fusarium & Fungal endophyte (Bayman \& Otero, 2006) \\
\hline C5 & Cylindrocarpon & Fungal endophyte (Fisher \& Petrini, 1989) \\
\hline C6 & Epulorhiza & Mycorrhizal (Shan et al, 2002) \\
\hline C7 & MUT 885 & Dark Septate Endophyte (Girlanda et al, 2002) \\
\hline C8 & Gliocladium catenulatum & $\begin{array}{l}\text { Biological control fungus (Paavanen-Huhtala et al, } \\
\text { 2004) }\end{array}$ \\
\hline C9 & Phomopsis & $\begin{array}{l}\text { Dark Septate Endophyte (from plant) (Jumpponen, } \\
\text { 2001) }\end{array}$ \\
\hline C10 & Phomopsis & Dark Septate Endophyte (from germinated seeds) \\
\hline
\end{tabular}




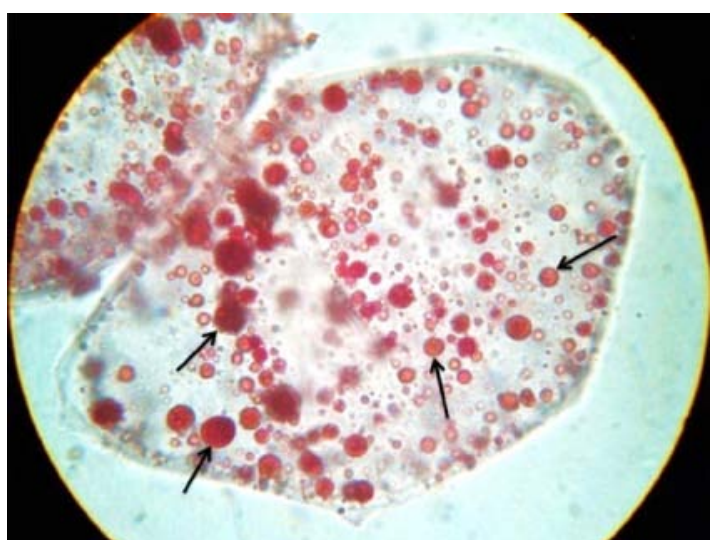

FIGURE 3. Two distinct microsclerotia (arrowheads) within th

Isolates 9 and 10 revealed $100 \%$ identity to Phomopsis sp XJ-05, and isolate 7 revealed 99\% identity to the fungal endophyte MUT 885 (a DSE fungus according to Girlanda et al., 2002), corroborating the results of the RFLP analysis. Phomopsis sp XJ-05 was isolated not only from the roots of $C$. irapeanum plants but also from the germinated seeds, indicating a possible role of stimulation of germination.

Other endophytic fungi belonging to the Deuteromycetes were also isolated: isolate 1 , identified as Fusarium sp 440 (99\% identity); isolate 4 identified as Fusarium sp (97\% identity); isolate 5 as Cylindrocarpon sp 4/97.1 (100\% identity); and isolate 8 as Gliocladium catenulatum ( $99 \%$ identity).

The genus Sistotrema is defined by Currah et al. (1990) as a mycorrhizal fungi of boreal species. Moncalvo et al., (2006) states that this fungus as a highly phylogenetic. However, analysis of ITS1-5.8ITS2 region sequences of our isolate $\mathrm{C} 2$ showed a high identity to this fungus.

Rhizoctonia is known for its association with most other orchids (Rasmussen, 1995). This fungus is a genus based on asexual stages, is a polyphyletic fungus which includes fungi from the families Tulasnellaceae, Sebacinaceae and Ceratobasidiaceae. Rhizoctonia solani is a known anamorph of Thanatephorus cucumeris, has been isolated from absorbent tissues of orchids and confirmed as mycorrhizal endophytes because are able to stimulate the seed germination and development of the plant in vitro assays (Warcup, 1971).

The Epulorrhiza species are known as anamorphs of the genus Rhizoctonia. Shan et al., 2002 mention

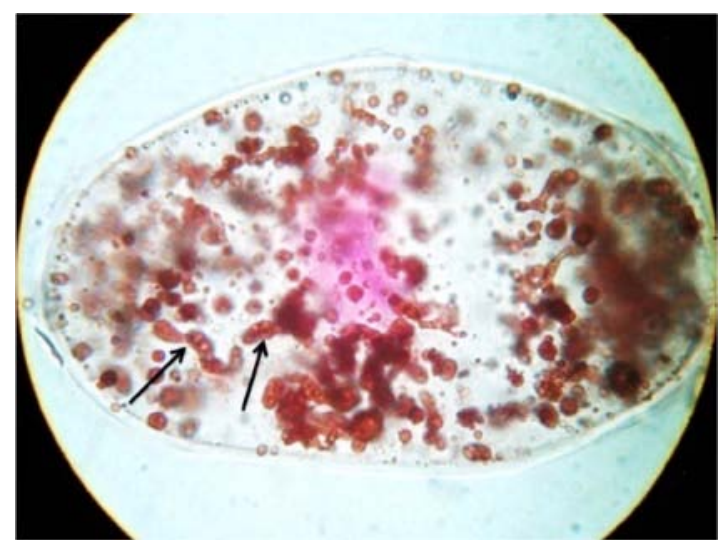

that certain species of this genus have been continually isolated of terrestrial orchids; by means of the RFLP and CAPS analysis of Rhizoctonia they were able to classify the genus and its anamorps in 4 groups. Group II formed by Epulorrhiza showed a high ability to stimulate the germination and growth of several orchids. In contrast Group I stimulate a specific orchid. Other authors (Sharma et al. 2003) found that in advanced development of the plant the number of species of Epulorrhiza is low suggesting that the occurrence of the fungus may be less critical in this growth stage.

DSE have been reported for nearly 600 plants host

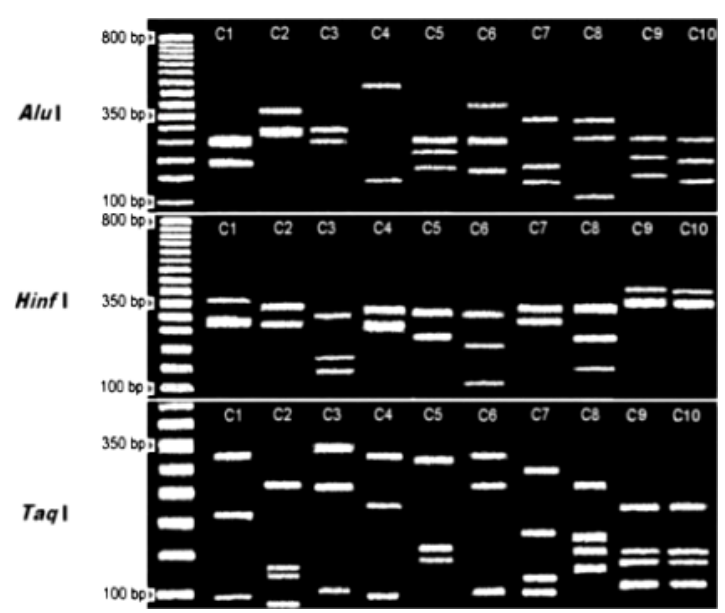

FIgURE 4. Restriction fragmen tlength polymorphisms obtained by endonucleases of the internal transcribed spacer (ITS1-5.8S-ITS2) region of the different fungi isolated from C. irapeanum. Digestions were performed with Alu 1, Hinf 1, and Taq 1. M=molecular weight marker. 


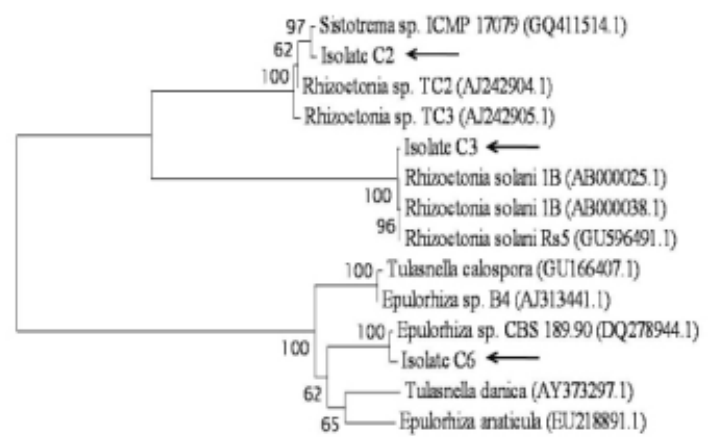

4.1

FiguRE 5. Neighbor-joining tree obtained from the internal transcribed spacer (ITS1-5.8S-ITS2) sequence alignment of isolates $\mathrm{C} 2, \mathrm{C} 3$ and $\mathrm{C} 6$ with sequences of Tulasnaceae. The Kimura two-parameter model was used for pairwise distance measurement. Bootstrap values above $50 \%$ are indicated (1000 replicates). Black arrows indicate the mycorrhizal fungal isolates recovered from the orchid C. irapeanum. Bar $=$ Kimura distance.

species, including plants known to bear different types of mycorrhizae occurring in highly diverse habitats.

Their widespread occurrence and high abundance suggests lack of host specificity and an important role in the different ecosystems (Jumpponen \& Trappe, 1988; Jumpponen, 1999). Jumpponen (2001) regards the DSE as nonconventional mycorrhizal symbiosis because some of them have found to enhance host mineral nutrition and growth (Fernando \& Currah, 1996). The presence of DSE in the germinated seeds of C. irapeanum and their lack in the ungerminated seeds suggests its possible role for the germination of the orchid seed.

In relation of the occurrence of Fusarium as an endophyte of Cypripedium, Bayman \& Otero (2006) have defined this genus and its telomorphs as a most interesting group of the orchids endophytes due to its hability to stimulate the seed germination of $C$. reginae.

Other found endophytes in C. irapeanum were Cylindrocarpum and Gliocladium. Cylindrocarpon sp. 4/97.1 was reported as an endophyte of roots of terrestrial orchids and mycoheterotrophic orchids (Bayman \& Otero, 2006). Gliocladium catenulatum is well known as a biological control agent (PaavanenHuhtala et al., 2004) and parasite of other fungi (Tu \& Vaartaja, 1980) suggesting an important role against pathogens in the orchid root.
ACKNOWLEDGEMENTS. This research was partially funded with a grant of the Instituto Plotécnico Nacional. RHV acknowledges support from CONACYT through a M Sc scholarship. We are grateful to Ms Raquel Escobedo for providing information on the ubication of the orchids. Thanks are due to Dr. Heidi Asbjornsen for constructive English corrections.

\section{LitERATURE CITED}

Bayman, P. \& J. Tupac Otero. 2006. In: Microbial Root Endophytes. B. Shultz, C. Boyle and T. Sieber, Eds. Springer, Heildeberg, New York. Pp 153-173.

Cribb, P. \& M. A. Soto-Arenas. 1993. The genus Cypripedium in Mexico and Central America. Orquídea (Mex.) 13:205-214.

Dearnaley, J. D. W. 2007. Further advances in orchid mycorrhizal research. Mycorrhiza 17: 475-486.

Currah, R. S., A. Smreciu, \& S. Hambleton. 1990. Mycorrhizae and mycorrhizal fungi of boreal species of Plantanthera and Coeloglossum (Orchidaceae). Canad. J. Bot. 68: 1171-1181.

Fernando, A. A. \& R. S. Currah. 1996. A comparative study of the effects of the root endophytes Leptodontidium orchidicola and Phaliocephala fortinii (Fungi Imperfecti) on the growth of some subalpine plants in culture. Canad. J. Bot. 74: 1071-1078.

Gardes, M. \& T. D. Bruns. 1993. ITS primers with enhanced specificity for basidiomycetes-Aplication to the identification of mycorrhizae and rusts. Molec. Ecol. 2:113-118.

Gardes, M. \& T. D. Bruns. 1996. Community structure of ectomycorrhizal fungi in Pinus muricata forest: aboveand below-ground views. Canad. J. Bot. 74: 1572-1573.

Gill, D. E. 1989. Fruiting failure, pollinator inefficiency, and speciation in orchids. In: D. Otte \& J. A. Endler (eds.), Speciation and its consequences. Sinauer Associates Sunderland, Massachusetts. Pp. 458-481.

Girlanda, M., S. Ghignone, \& A. M. Luppi. 2002. Diversity of sterile root-associated fungi of two mediterranean plants. New Phytol. 155: 481-498.

Hadley, G. 1970. Non-specificity of symbiotic infection in orchid mycorrhiza. New Phytol. 69: 1015-1023.

Henrion, B. F., F. Le-Tacon \& F. Martin. 1992. Rapid identification of genetic variation of ectomycorrhizal fungi by amplification of ribosomal RNA genes. New Phytol. 122: 289-298.

Jumpponen, A. 1999. Spatial distribution of discrete RAPD phenotypes of a root endophytic fungus, Phialocephala fortinii, at a primary successional site on a glacier forefront. New Phytol. 141: 333-344. 
Jumpponen, A. 2001. Dark septate endophytes - are they mycorrhizal? Mycorrhiza 11: 207-211.

Jumpponen, A. \& J. M. Trappe. 1998. Dark Septate Endophytes: A review of facultative biotrophic rootcolonizing fungi. New Phytol. 140: 295-310.

Knudson, L. 1946. A new nutrient solution for the germination of orchid seed. Amer. Orch. Soc. Bull. 214217.

Molina, R. \& J. G. Palmer. 1982. Isolation, maintenance and pure culture manipulation of ectomycorrhizal fungi. In: Schenck N.C. (ed.), Methods and principles of mycorrhizal research. Amer. Phytopathol. Soc., St. Paul Minnesota. Pp. 115-129.

Moncalvo, J-M., R. H. Nilsson, B. Koster, S. M. Dunham, T. Bernauer, P. B. Matheny, T. M. Torner, S. Margaritescu, M. Weiß, E. Danell, G. Langer, E. Langer \& K-H. Larsson. 2006. The cantharelloid clade: dealing with incongruent gene trees and phylogenetic reconstruction methods. Mycologia 98:937-948.

Ortega-Larrocea, M. P. \& M. Rangel-Villafranco. 2007. Fungus assisted reintroduction and longtem survival of two Mexican terrestrial orchids in the natural hábitat. Lankesteriana 7: 317-321.

Paavanen-Huhtala, S., H. Avikainen\& T. Yli-Mattil. 2004. Development of strain-specific primers for a strain of Gliocadium catenulatum used in biological control. Eur. J. Pl. Pathol. 105: 187-198.

Phillips, J. M. \& D. S. Hayman. 1970. Improvement procedures for clearing and staining parasitic and vesicular-arbuscular mycorrhizal fungi for rapid assessment of infection. Trans. Brit. Mycol. Soc. 55: 158-161.

Rasmussen, H. N. 1995. Terrestrial Orchids: From Seed to Mycotrophic Plant. Cambridge University Press, Cambridge, UK.

SEMARnat. 1995. Gaceta Ecológica 7: 1-72.

Shan, X. C., E. C. Y. Liew, M. A. Weatherhead \& I. J. Hodgkiss. 2002. Characterization and taxonomic placement of Rhizoctonia-like endophytes from orchid roots. Mycol. 94:230-239.

Sharma, J., L. W. Zettler \& J. W. van Sambeek. 2003.
A survey of mycobionts of federally threatened Platanthera praeclara (Orchidaceae). Symbiosis 34: 145-155.

Shefferson, R. P., M. Weiß, T.I.I.U. Kull \& D. Lee Taylor. 2005. High specificity generally characterizes mycorrhizal association in rare lady's slipper orchids, genus Cypripedium. Molecul. Ecol. 14: 613-626.

Shimura, H., M. Sadamoto, M. Matsuura, T. Kawahara, S. Naito \& Y. Koda. 2009. Characterization of mycorrhizal fungi isolated from the threatened Cypripedium macranthos in a northen island of Japan: two phylogenetically distinct fungi associated with the orchid. Mycorrhiza 19:525-534.

Smith, S. E. \& D. J. Read. 1997. Mycorrhizal Symbiosis. Academic Press. Pp. 347-357.

Smith, M. E., G. W. Douhan \& D. M. Rizzo. 2007. Intra-specific and intra-sporocarp ITS variation of ectomycorrhizal fungi as assessed by rDNA sequencing of sporocarps and pooled ectomycorrhizal roots from Quercus woodland. Mycorrhiza 18:15-22.

Suárez, J. P., M. Weiss, A. Abele, S. Garnica, F. Oberwinkler, \& I. Kottke. 2006. Diverse tullasnelloid fungi form mycorrhizas with epiphytic orchids in an Andean cloud forest. Mycol. Res. 110: 1257-1270.

Schulz, B. \& C. Boyle. 2005. The endophytic continuum. Mycol. Res. 109:661-687.

Thompson, J. D., D. G. Higgins \& T. J. Gibson. 1994. CLUSTAL W: improving the sensitivity of progressive multiple sequence alignment through sequence weighting, positions-specific gap penalties and weight matrix choice. Nucleic Acids Res 22: 4673-4680 doi:10.1093/NAR/22.22.4673.

Tu, J. C. \& O. Vaartaja. 1980. The effect of the hyperparasite Gliocadium virens on a Rhizoctonia root rot of white beans. Canad. J. Bot. 59: 22-27.

Valdés, M., A. Espinosa \& C. Trejo. 2005. Pichohuastle: orquídea nativa mexicana en peligro de extinción. Conversus (Instituto Politécnico Nacional) 38: 30-33.

Warcup, J. H. 1971. Specificity of mycorrhizal association in some Australian terrestrial orchids. New Phytol. 70: 41-46. 